
\title{
R Reserach S Suare \\ Genetic Diversity of Staphylococcus Saprophyticus Strains Causing Urinary Tract Infections in Lagos Metropolis
}

Felix Oluwasegun Alao ( $\square$ sunfelixnaija@gmail.com )

Bells University of Technology https://orcid.org/0000-0002-7706-6011

Stella Ifeanyi Smith

Nigerian Institute of Medical Research, Yaba, Lagos

Emmanuel Adedayo Omonigbehin

Covenant University, Canaanland, Ota, Nigeria

Isaac Adeyemi Adeleye

University of Lagos, Akoka, Lagos

Research article

Keywords: Staphylococcus saprophyticus, 16SrRNA gene, Phylogenetic analysis, Isolates, Sequence

Posted Date: December 3rd, 2020

DOI: https://doi.org/10.21203/rs.3.rs-117287/v1

License: (c) (i) This work is licensed under a Creative Commons Attribution 4.0 International License.

Read Full License 


\section{Abstract}

Background: Staphylococcus saprophyticus is a Gram-positive bacterium implicated in urinary tract infections in sexually active women along with other bacteria. There is a special need to accurately isolate and identify this organism in clinical specimens in order to prevent misidentification in the laboratory. The present study was carried out to evaluate the genetic diversity of one hundred different Staphylococcus saprophyticus strains isolated from women presenting with urinary tract infections reporting in four government hospitals in Lagos Metropolis using 16SrRNA gene sequence analysis.

Results: The PCR-amplified and sequenced 16SrRNA gene of 100 isolates and confirmed 88 strains of $S$. saprophyticus to subspecies level, while 8 belong to other genera and 4 could not be ascertained due to low significant similarity. Phylogenetic analysis showed the interrelationship between the isolates from different hospitals. The results showed the distribution of the isolates into two broad clusters and twentytwo sub-clusters.

Conclusion: The results revealed the genetic diversity of Staphylococcus saprophyticus isolated from women with urinary tract infections in Lagos Metropolis using 16SrRNA gene sequence.

\section{Background}

Urinary tract infection (UTI) is the presence of micro-organism in the urinary tract including urinary bladder, prostate, collecting system or kidney. It is the second most common encountered infection in clinical practice. The syndrome ranges from asymptomatic bacteriuria to perinephric abscess with sepsis [1]. Worldwide, about 150 million people are diagnosed with UTI each year costing the global economy in excess of 6 billion US dollars [2]. An estimated $40-50 \%$ of all women will experience at least one UTI in their lifetime, and one in three women would have had at least one clinically diagnosed UTI by the age of 24 [3].

Staphylococcus saprophyticus is implicated in UTI and it accounts for $5-10 \%$ of hospital visit globally [4]. It is estimated that $S$. saprophyticus causes up to one million UTI each year and it is the second most common cause of uncomplicated UTI in sexually active women $[5,6]$. Over $40 \%$ of young, sexually active women are colonized with $S$. saprophyticus in the rectum, urethra, or cervix at any given time [7].

Staphylococcus belongs to the Gram-positive low GC content group of the Firmicutes division of bacteria. Three species: Staphylococcus aureus, Staphylococcus epidermidis, and Staphylococcus saprophyticus are recognized as major human pathogens [8]. As they are widely spread in various niches such as clinical, environment and food manufacturing plants, it has become increasingly important to accurately identify the staphylococci at the genus and species levels. The conventional phenotypic tests used for the identification of Staphylococcus species have limitations [9, 10], thus several molecular methods have been developed [11]. These include DNA-DNA hybridization and 16S rRNA sequencing, as well as various PCR-based techniques $[12,13]$. 
In Nigeria, S. saprophyticus is often misidentified as S. aureus. Ayeni and Odumosu [14] reported 85\% misidentification rate of $S$. aureus in the Southern Nigerian States of Edo, Rivers, Bayelsa, Ekiti, Osun, Oyo, Ogun and Lagos.

In view of the emerging clinical importance of this organism, proper identification is of utmost importance for correct diagnosis.

The aim of the present study was to use 16SrRNA gene to determine the genetic diversity of $S$. saprophyticus strains isolated from women presenting with urinary tract infections in government hospitals in Lagos metropolis.

\section{Results}

\section{Bacterial Isolates}

The biochemical analyses showed all isolates to be Gram positive cocci, catalase positive, oxidase and coagulase negative and all were strictly resistant to $5 \mu \mathrm{g}$ novobiocin disc (Oxoid, UK), while 98 were urease positive, 66 showed lipase activity, 80 showed haemagglutination of sheep erythrocyte and 93 were hydrophobic (Table 1).

\section{Molecular identification of the isolates}

In the present study, the 1500 bp partial 16SrRNA gene sequences of 100 bacterial isolates were PCRamplified, sequenced (Figure 1) and the resulting data deposited in the GenBank database and accession numbers assigned (Table 2). In total, 88 (88\%) out of 100 isolates sequenced were confirmed as $S$. saprophyticus species and subspecies whereas the biochemical tests identified all as $S$. saprophyticus. In this study, 4 (4\%) isolates were confirmed as Escherichia coli earlier identified as S. saprophyticus; 2 (2\%) as Enterococcus faecalis, 1 (1\%) Enterobacter cowanii and 1 (1\%) Enterobacter cloacae. While 4 (4\%) isolates could not be adequately identified using 16SrRNA gene due to low significant similarity when it was compared with other sequences in the GENBANK. For comparison purposes, the submitted 16SrRNA gene sequences of $S$. saprophyticus from different parts of the world were downloaded from the GenBank database.

\section{Phylogenetic analysis of the $S$. saprophyticus strains}

The phylogenetic analysis confirmed the effectiveness of 16SrRNA gene as a means of isolates identification. The cladogram showed that the strains of $S$. saprophyticus based on their evolutionary closeness were broadly divided into two groups which comprises of 22 clusters with Group A having 16 clusters while Group B had 6 clusters (Figure 2). The tree showed that the strains FELAO56 and 78 and FELA011 and 47 were the most closely related species sharing the same sister nodes. Strains FELAO47 
and 11 were obtained from different hospitals with $100 \%$ bootstrap value followed by strains FELA036 and 86, 69 and 87 with 99\% bootstrap value. Strains FELAO32 and 51 and FELAO93 and 94 had $98 \%$.

The strain FELA015 was phylogenetically closely related with the $S$. saprophyticus strain FVRI with accession number KP698299 isolated from India; likewise strain FELAO49 was related to strain JNS3 (KC503908) isolated from China. They belonged to the same cluster although the isolates were obtained from different hospitals. The other isolates obtained from different parts of the world were closely related forming a single cluster $\{16\}$.

\section{Discussion}

Staphylococci are opportunistic pathogens that can cause diverse range of infections. Therefore, appropriate identification method must be put in place in order to distinguish different groups of this organism with a view to ensuring better management of diseases caused by the organism.

Accurate identification at the species level may not only change the diagnosis but can also help to identify unusual antimicrobial resistance patterns. The ideal method should have high discriminatory power and allow the identification of closely related species while also being relatively simple, inexpensive, rapid and reproducible. Therefore, genetic methods based on PCR or sequencing are good candidates for identification purposes [15].

The 16S rRNA gene is widely distributed throughout the genome and useful for bacterial identification [16]. The 16S rRNA gene is a part of $30 \mathrm{~S}$ ribosome and is around $1500 \mathrm{bp}$ and is highly stable. Due to stability, it is widely used in molecular identification, taxonomic studies, and phylogenetic and evolutionary studies [17]. Das et al. [18], Egege et al. [19], Hardy et al. [20] and Syromyatnikov et al. [21] in their studies had also shown the effectiveness and precision in using 16S rRNA gene sequence-based assay for the identification of bacterial isolates obtained from different samples. In our study, we used PCR sequencing of 16SrRNA gene to effectively confirm Staphylococcus saprophyticus strains previously identified using biochemical and phenotypic characterisation. Mellmann et al. [22], Shukla et al. [23], Darmawati et al. [24], and Srinivasan et al. [25] had used the 16S rRNA gene sequence analysis for the identification of staphylococcal isolates from environmental and clinical samples. In this study, the identification of the $88(88 \%)$ S. saprophyticus strains is in agreement with results of studies carried out by Kosecka-Strojek et al. [15], Woo et al. [26] and Bosshard et al. [27] that confirmed usefulness of 16SrRNA gene in the identification of bacterial isolates.

The phylogenetic analysis revealed that $S$. saprophyticus strains from Lagos Mainland are closely related while most of the strains from Lagos Island were found to be phylogenetically diverse from that of Mainland except strain FELA011 (GHM) that was highly related to strain FELAO47 (GHS) with 100\% bootstrap value.

The sequence similarity of $16 \mathrm{SrRNA}$ gene ranged from 76 to $95 \%$ in all isolates. To the best of our knowledge, this is the first time that the PCR amplicons of the $S$. saprophyticus strains from this 
environment will be sequenced and the resulting data deposited in the GenBank data.

\section{Conclusion}

The sequence-based identification of isolates has tremendous advantage over biochemical and phenotypic characterizations in that it can identify isolates to subspecies level. Therefore, clinical laboratories should be mandated to include $S$. saprophyticus in the list of possible pathogens in the case of bacteriuria and UTI cases. This would prevent misdiagnosis, help the clinicians to give a better diagnosis and treatment regimen. The findings have shown the occurrence and diversity of Staphylococcus saprophyticus strains in this environment.

\section{Methods}

\section{Study design}

A total of 384 urine samples were collected once from women reporting for gynaecological care and those presenting with urinary tract infections in government hospitals in Lagos State from February 2014 to April 2016. Pregnant women were excluded from this study, while only women in the age group from 20 to 50 years were included. The participants in this study were instructed on how to collect first morning urine in a sterile universal bottle through the clean-catch midstream method.

\section{Bacterial strains and culture conditions}

The isolates were collected from four different hospitals with three located in the mainland (General Hospital, Gbagada $\{\mathrm{GHG}\}$, General Hospital, Somolu $\{\mathrm{GHS}\}$ and Lagos University Teaching Hospital $\{$ LUTH\}) and one in island part of the state (General Hospital, Marina $\{G H M\})$. One hundred and twenty-six isolates were obtained from the Department of Medical Microbiology, LUTH; eighty-one isolates from $\mathrm{GHM}$; one hundred and sixteen isolates from GHG and sixty-one isolates from GHS. The reference strain (Staphylococcus saprophyticus subsp. bovis DSM 18669) was obtained from Leibniz-Institut DSMZ, Germany.

One millilitre of the urine sample was inoculated into $9 \mathrm{~mL}$ of brain heart infusion broth (Himedia, India) containing $5 \mu \mathrm{g} / \mathrm{mL}$ of novobiocin (Oxoid, UK). The samples were then transported to the Microbiology Laboratory of the Bells University of Technology, Ota; where further analyses were carried out. After $24 \mathrm{~h}$ of incubation at $37^{\circ} \mathrm{C}$, a loopful from broth medium was streaked on to brain heart infusion agar (Himedia, India) plate containing $5 \mu \mathrm{g} / \mathrm{mL}$ of novobiocin. The organism was incubated overnight at $37^{\circ} \mathrm{C}$ for $24 \mathrm{~h}$ [7]. The isolates were frozen at $-80^{\circ} \mathrm{C}$ in brain heart infusion broth containing $10 \%$ glycerol until the study.

\section{Biochemical identification / phenotypic characterisation}


The isolates were Gram stained and tested for production of oxidase, catalase, coagulase, urease, resistance to $5 \mu \mathrm{g}$ novobiocin disc (Oxoid, UK) [28], lipase activity [29, 30], haemagglutination assay, and hydrophobicity test [30] for the preliminary identification. A total of 100 novobiocin resistant isolates were processed and analysed genotypically.

\section{Molecular analyses of Staphylococcus saprophyticus isolates}

\section{DNA Isolation}

Genomic DNA of the $S$. saprophyticus isolates was extracted using QIAGEN DNA extraction kit (QIAGEN, Germany) in accordance to manufacturer instruction with minor modification that $180 \mu \mathrm{L}$ of lysozyme $(10 \mu \mathrm{g} / \mathrm{mL})$ was added at the cell lysis stage. The crude DNA extract was kept at $-80^{\circ} \mathrm{C}$ until it was used for PCR amplification.

\section{PCR Amplification}

The molecular confirmation of the isolates was carried out using 16S rRNA primers: 27F: 5'AGAGTTTGATCCTGGCTCAG-3'; 1492R: 5'-GGTTACCTTGTTACGACTT-3' [31]. For all S. saprophyticus strains, amplification was performed from purified genomic DNA. The PCR amplification was performed in a $25 \mu \mathrm{L}$ reaction mixture containing $2.5 \mu \mathrm{L}$ of $10 x$ EasyTaq® Buffer, $2 \mu \mathrm{L}$ of $2.5 \mathrm{mM}$ dNTPs, $0.5 \mu \mathrm{L}$ of EasyTaq® DNA Polymerase (Transgen Biotech, China), $1 \mu \mathrm{L}(5 \mu \mathrm{M})$ for each of the primers and $3 \mu \mathrm{L}$ of template DNA and final volume was brought to $15 \mu \mathrm{L}$ with distilled water. PCR reaction was carried out in accordance with the modified method of Ferreira da Silva et al. [32] with initial denaturation of $5 \mathrm{~min}$ at $95^{\circ} \mathrm{C}, 30$ cycles of final denaturation at $94^{\circ} \mathrm{C}$ for $30 \mathrm{~s}$, annealing of $30 \mathrm{~s}$ at $52^{\circ} \mathrm{C}$, initial elongation of 1 min $25 \mathrm{~s}$ at $72^{\circ} \mathrm{C}$ and final elongation step at $72^{\circ} \mathrm{C}$ for $10 \mathrm{~min}$ was applied in a BIO-RAD C1000 touch thermal cycler.

PCR products were analysed by electrophoresis in 1\% (w/v) agarose gel in 1X TBE buffer. The PCR reaction mixture was stained with $1 \%$ solution of ethidium bromide $(\mathrm{CDH}$, India) and visualized using UVP Benchtop UV Transilluminator (BioDoc-lt). The sizes of the amplicon were compared with $100 \mathrm{bp}$ DNA ladder (New England Biolabs, USA).

\section{S rRNA Sequencing}

The purification and sequencing of the amplified PCR products were carried out using the Sanger sequencing method. It was carried out in Macrogen Laboratory in Maryland USA. The samples were first purified using Zymo PCR cleanup Kit. Purified samples were sequenced using Applied Biosystems 
Seqstudio Genetic Analyzer. Sequencing analysis was performed on the $1500 \mathrm{bp}$ PCR product. The 100 16S rRNA sequences were aligned and compared with other 16S rRNA genes in the GenBank by using the NCBI Basic Local Alignment Search Tools (BLAST-n) programme. (http://www.ncbi.nlm.nih.gov/BLAST).

\section{Phylogenetic Analysis}

\section{Phylogenetic construction of 16S rRNA gene sequences}

In this study, phylogenetic tree was constructed to show interrelationship between all the 88 strains of $S$. saprophyticus obtained in this study and 11 strains from different parts of the world. The evolutionary history was inferred using the Neighbour-Joining method. The optimal tree with the sum of branch length $=4.24945984$ is shown. The evolutionary distances were computed using the Maximum Composite Likelihood method and are in the units of the number of base substitutions per site. The analysis involved 99 nucleotide sequences. All ambiguous positions were removed for each sequence pair. There were a total of 1827 positions in the final dataset.

Pairwise and multiple alignments of $16 \mathrm{~S}$ rRNA gene sequences of $S$. saprophyticus were carried out using Clustal W [33]. Phylogenetic and molecular evolutionary analyses were conducted using MEGA version 6 [34].

\section{Abbreviations}

PCR: Polymerase chain reaction; \%: Percentage; UTI: Urinary tract infection; GC: Guanine Cytosine; DNA: Deoxyribonucleic acid; UK: United Kingdom; bp: Base pairs; GHM: General Hospital, Marina; GHS: General Hospital, Somolu; GHG: General Hospital, Gbagada; LUTH: Lagos University Teaching Hospital; DSM: Deutsche Sammlung von Mikroorganismen; SrRNA: Ribosomal ribonucleic acid; $\mathrm{mL}$ : Millilitre; $\mu \mathrm{g} / \mathrm{mL}$ : Microgramme per milliliter; ${ }^{\circ} \mathrm{C}$ : Degree Celsius; $\mathrm{h}$ : Hour; $\mu \mathrm{g}$ : Microgramme; $\mu \mathrm{L}$ : Microlitre; $\mu \mathrm{M}$ : Micromolar; dNTPs: Deoxyribonucleotide triphosphates; s: Second; min: Minute; w/v: Weight per volume; CDH: Central Drug House; UV: Ultraviolet; USA: United States of America; NCBI: National Centre for Biotechnology Information; MEGA: Molecular evolutionary genetics analysis

\section{Declarations}

\section{Ethics approval and consent to participate}

This study formed part of a thesis for Doctor of Philosophy (PhD) degree in Microbiology and was approved by the Department of Microbiology, Faculty of Science, University of Lagos, the Health Research and Ethics Committee (ADM/DCST/HREC/879) of the Lagos University Teaching Hospital (LUTH), IdiAraba, Lagos and the Institutional Review Board of Nigerian Institute for Medical Research, Lagos. The written informed consent was obtained from each of the study participants before enrolment. 


\section{Consent for publication}

Not applicable

\section{Availability of data and materials}

The datasets used and/or analysed during the current study are available from the corresponding author on reasonable request.

\section{Competing interests}

The authors declare that they have no competing interests

\section{Funding}

None to declare

\section{Author's contributions}

FA carried out the experimental work and wrote the manuscript, SS coordinated the work, EO assisted in experimental work, IA coordinated the work and edited the manuscript. All authors contributed to the writing of the manuscript and approved the final manuscript.

\section{Acknowledgements}

Not applicable

\section{Author information}

${ }^{1}$ Department of Microbiology, Faculty of Science, University of Lagos, Lagos, Nigeria

${ }^{2}$ Department of Molecular Biology and Biotechnology, Nigerian Institute for Medical Research, Yaba, Lagos, Nigeria

${ }^{3}$ Department of Biological Sciences, Covenant University, Ota, Ogun State, Nigeria

${ }^{4}$ Department of Biological Sciences, Bells University of Technology, Ota, Ogun State, Nigeria 


\section{ORCID}

Felix Oluwasegun Alao: 0000-0002-7706-6011

Stella Smith: 0000000321631189

\section{References}

1. Johnson CC. Definition, classification, and clinical presentation of urinary tract infections. Med Clin North Am. 1991;75(2):241-43.

2. Gonzalez CM, Schaeffer AJ. Treatment of urinary tract infection: what's old, what's new, and what works. World J Urol. 1999;17(6):372-82.

3. Foxman B, Barlow R, D'Arcy H, Gillespie B, Sobel JD. Urinary tract infection: self-reported incidence and associated costs. Ann Epidemiol. 2000;10(8):509-15.

4. Odoki M, Aliero AA, Tibyangye J, Maniga JN, Wampande E, Kato CD, et al. Prevalence of bacterial urinary tract infections and associated factors among patients attending hospitals in Bushenyi District, Uganda. Int. J. Microbiol. 2019;2019: Article ID3183076, 5 pages.

5. Nicolle LE. Uncomplicated urinary tract infection in adults including uncomplicated pyelonephritis. Urol Clin North Am. 2008;35(1):1-12.

6. King NP, Sakinc T, Ben Zakour NL, Totsika M, Heras B, Simerska P, et al. Characterisation of a cell wall-anchored protein of Staphylococcus saprophyticus associated with linoleic acid resistance. BMC Microbiol. 2012; 8(12):1-12.

7. Rupp ME, Soper DE, Archer GL. Colonization of the female genital tract with Staphylococcus saprophyticus. J Clin Microbiol. 1992;30(11):2975-79.

8. Kuroda M, Yamashita A, Hirakawa H, Kumano M, Morikawa K, Higashide M, et al. Whole genome sequence of Staphylococcus saprophyticus reveals the pathogenesis of uncomplicated urinary tract infection. Proc Natl Acad Sci USA. 2005;102:13272-

9. Rossi F, Tofalo R, Torriani S, Suzzi G. Identification by 16S-23S rDNA intergenic region amplification, genotypic and phenotypic clustering of Staphylococcus xylosus strains from dry sausages. J Appl Microbiol. 2001;90: 365-71.

10. Morot-Bizot S, Talon R, Leroy-Setrin S. Development of specific PCR primers for a rapid and accurate identification of Staphylococcus xylosus, a species used in food fermentation. J Microbiol Met.2003;55:279-86.

11. Morot-Bizot SC, Talon R, Leroy S. Development of a multiplex PCR for the identification of Staphylococcus genus and for staphylococcal species isolated from food. J Appl Microbiol. 2004;97:1087-94.

12. De Buyser M-L, Morvan A, Aubert S, Dilasser F, el Solh N. Evaluation of a ribosomal RNA gene probe for the identification of species and subspecies within the genus Staphylococcus. J Gen Microbiol. 1992;138:889-99. 
13. Freney J, Kloos WE, Hajek V, Webster JA, Bes M, Brun Y, et al. Recommended minimal standards for description of new staphylococcal species. Subcommittee on the taxonomy of staphylococci and streptococci of the International Committee on Systematic Bacteriology. Int J Syst Bacteriol. 1999;49:489-502.

14. Ayeni FA, Odumosu BT. False identification of other microorganisms as Staphylococcus aureus in Southern Nigeria. Tropical J Pharm 2016;15(9):1941-45.

15. Kosecka-Strojek M, Sabat AJ, Akkerboom V, Becker K, van Zanten E, Wisselink G, et al. Development and validation of a reference data set for assigning Staphylococcus species based on nextgeneration sequencing of the 16S-23S rRNA region. Front Cell Infect Microbiol. 2019;9:278.

16. Woo PC, Teng JL, Wu JK, Leung FP, Tse H, Fung AM, et al. Guidelines for interpretation of 16S rRNA gene sequence-based results for identification of medically important aerobic Gram-positive bacteria. J Med Microbiol. 2009;58:1030-

17. Singh V, Chaudhary DK, Mani I. Molecular characterization and modeling of secondary structure of 16S rRNA from Aeromonas veronii. Int J Appl Biol Pharm Technol 2012;3:253-

18. Das A, Behera BK, Acharya S, Paria P, Chakraborty HJ, Parida PK, et al. Genetic diversity and multiple antibiotic resistance index study of bacterial pathogen, Klebsiella pneumoniae strains isolated from diseased Indian major carps. Folia Microbiol. 2019;64:875-87.

19. Egege SR, Akani NP, Nwankwo CEl. Detection of methicillin-resistant Staphylococcus aureus in readyto-eat shellfish (Corbiculid heterodont) in Bayelsa State, Nigeria. Microbiol Res J Int. 2020;30(3): 2235 .

20. Hardy L, Bansal G, Hewlett KH, Arora A, Schaffer SD, Kamau E. Antimicrobial activity of clinically isolated bacterial species against Staphylococcus aureus. Frontiers in Microbiology 2020;10:Article 2977.

21. Syromyatnikov MY, Kokina AV, Solodskikh SA, Panevina AV, Popov ES, Popov VN. High-throughput $16 S$ rRNA gene sequencing of butter microbiota reveals a variety of opportunistic pathogens. 2020;9:608.

22. Mellmann A, Becker K, von Eiff C, Keckevoet U, Schumann P, Harmsen D. Sequencing and staphylococci identification. Emerging infectious diseases. 2006;12(2):333-5.

23. Shukla P, Srivastava S, Srivastava R, Rawat AK. Sequencing of $16 S$ rRNA gene for identification of Staphylococcus species in water sample. African J Microbiol Res. 2011;5(29):5142-46.

24. Darmawati S, Asmara W, Kawaichi M. Identification of Staphylococcus strains isolated from positive widal blood based on 16S rRNA gene sequences, Int J Sci Eng. 2015;9(2):97-100.

25. Srinivasan R, Karaoz U, Volegova M, MacKichan J, Kato-Maeda M, Miller S, et al. Use of 16S rRNA gene for identification of a broad range of clinically relevant bacterial pathogens. PLoS ONE. 2015;10(2): e0117617.

26. Woo PC, Ng KH, Lau SK, Yip KT, Fung AM, Leung KW, et al. Usefulness of the MicroSeq $50016 \mathrm{~S}$ ribosomal DNA-based bacterial identification system for identification of clinically significant 
bacterial isolates with ambiguous biochemical profiles. J Clin Microbiol. 2003;41:1996-2001.

27. Bosshard PP, Abels S, Zbinden R, Bottger EC, Altwegg M. Ribosomal DNA sequencing for identification of aerobic Gram-positive rods in the clinical laboratory (an 18-month evaluation). J Clin Microbiol. 2003;41:4134-40.

28. Ferreira AM, Bonesso MF, Mondelli AL, da Cunha Mde L. Identification of Staphylococcus saprophyticus isolated from patients with urinary tract infection using a simple set of biochemical tests correlating with 16S-23S interspace region molecular weight patterns. J. Microbiol. Methods. 91;(2012):406-11.

29. Nikoleit K, Rosenstein R, Verheij HM, Götz F. Comparative biochemical and molecular analysis of the Staphylococcus hyicus, Staphylococcus aureus and a hybrid lipase. Indication for a C-terminal phospholipase domain. Eur J Biochem. 1995;228:732-8.

30. Kleine B, Gatermann S, Sakinc T. Genotypic and phenotypic variation among Staphylococcus saprophyticus from human and animal isolates. BMC Research Notes. 2010;3:163.

31. Lane DJ. 16S/23S rRNA sequencing. In: Stackebrandt E., and Goodfellow, M. (eds). Nucleic acid techniques in bacterial systematics. John Wiley \& Sons, New York. 1991; 115-75.

32. Ferreira da Silva M, Vaz-Moreira I, Gonzalez-Pajuelo M, Nunes OC, Manaia CM. Antimicrobial resistance patterns in Enterobacteriaceae isolated from an urban wastewater treatment plant. FEMS Microbiol Ecol. 2007;60:166-76.

33. Thompson JD, Higgins DG, Gibson TJ. CLUSTAL W: improving the sensitivity of progressive multiple sequence alignment through sequence weighting, position-specific gap penalties and weight matrix choice. Nucleic Acids Res. 1994;22(22):4673-80.

34. Tamura K, Stecher G, Peterson D, Filipski A, Kumar S. MEGA 6: Molecular evolutionary genetics analysis version 6.0. Mol Biol Evol. 2013;30:2725-29.

\section{Tables}

Due to technical limitations, table 1 and table 2 are only available as a download in the Supplemental Files section.

\section{Figures}




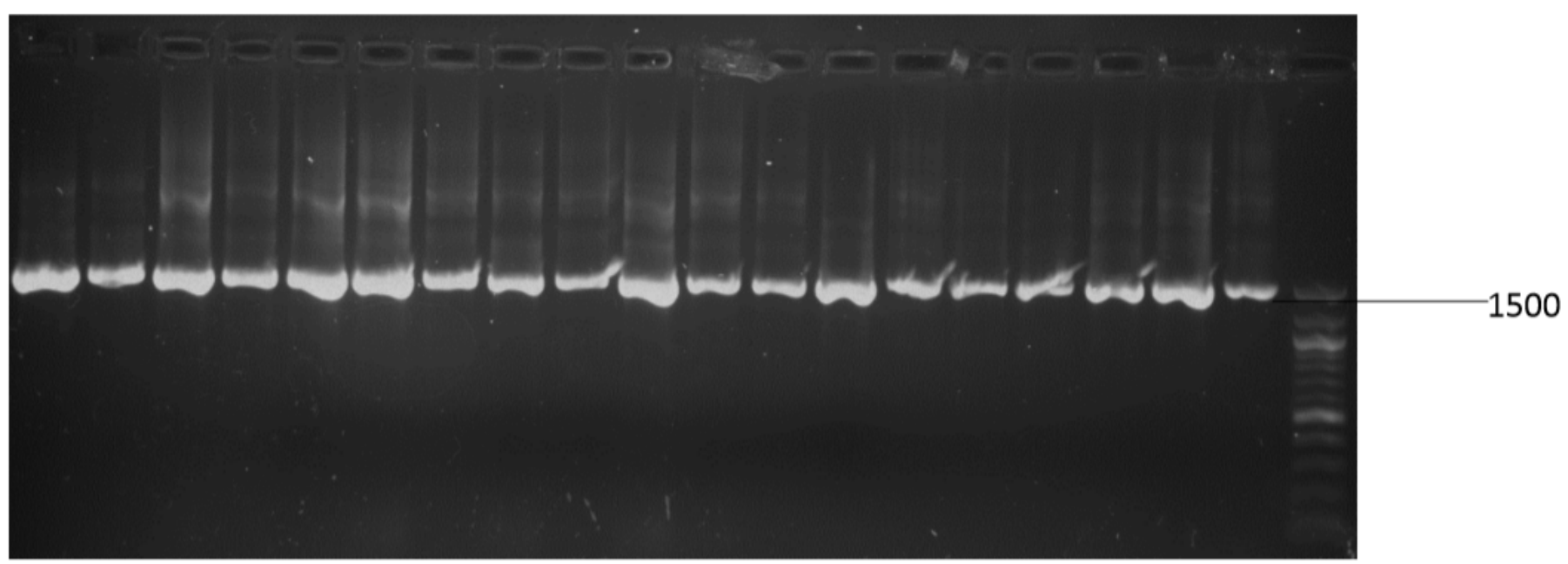

\section{Figure 1}

PCR amplification of 16SrRNA gene universal primer (27F/1492R) of Staphylococcus saprophyticus from urine samples. Lane M: 100 bp DNA Ladder. 


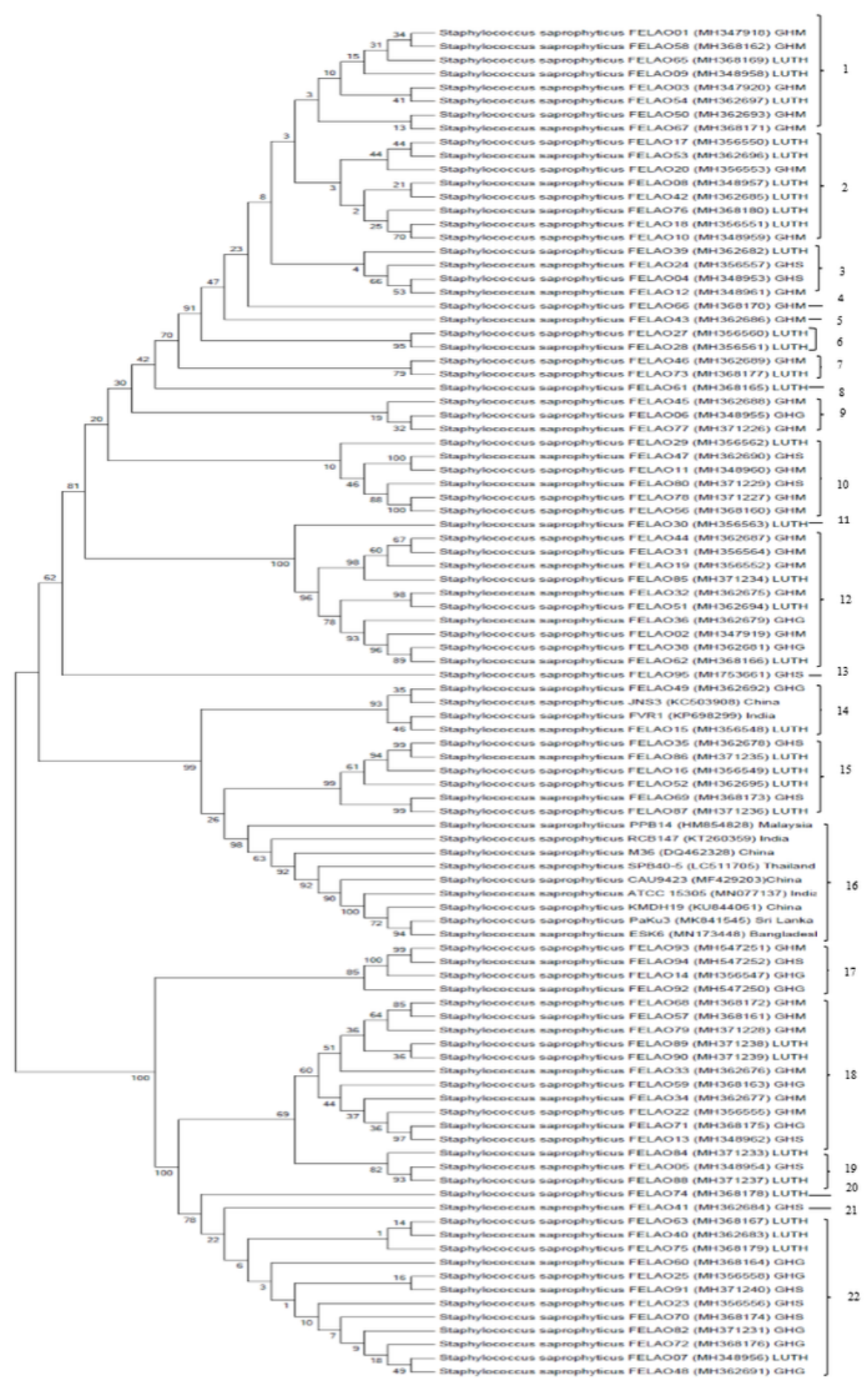

Figure 2

Neighbour-joining tree showing the phylogenetic relationships among S. saprophyticus isolates based on a comparison of 1500bp 16SrRNA gene sequences. Bootstrap values based on 1000 replicates are given at the branching points when they are above $50 \%$. NCBI accession numbers are in parentheses followed by sampling site. 


\section{Supplementary Files}

This is a list of supplementary files associated with this preprint. Click to download.

- BMCJointTreeoriginal.pdf

- OriginalGelFigurepdf.pdf

- BMCTable.pdf 